\title{
Antibacterial Effect of some Mineral Clays In Vitro
}

\author{
Shehab A. Lafi ${ }^{1}$ and Mohammed R. Al-Dulaimy ${ }^{2}$ \\ 1- Microbiology Department, College of Medicine / Anbar University West of IRAQ \\ 2- Microbiology Department, College of Dentistry, Anbar University. \\ Email Shehab58@yahoo.com
}

\begin{abstract}
Background:- The use of geological mineral clay to heal bacterial infections has been evident, since the earliest recorded history, and specific clay minerals may prove valuable in the treatment of bacterial diseases, including infections for which there are no effective antibiotics, such as multi-drug resistant infections.
\end{abstract}

Objectives:- The aim of this study is to identify new inhibitory agents in an era when bacterial antibiotic resistance continues to challenge human health and the availability of new antimicrobial compounds is limited.

Materials and methods:- Two bacterial isolates were taken from patient with different infections (UTI, skin infection). The two isolates were used to study the antibacterial effect of four types of mineral clays (gray clay, yellow clay, white clay, and pink clay).

Result:- Three types of clays (white clay, gray clay, and yellow clay,) have an antibacterial effect against Staphylococcus aureus that was isolated from skin infection. And have no effect against Pseudomonas aeruginosa that was isolated from patient with UTI. On the other hand, pink mineral clay explained an antibacterial effect against Pseudomonas aeruginosa, and has low effect against Staphylococcus aureus.

Conclusions:- Our results indicated that mineral clay could provide an alternative treatment against numerous human bacterial infections.

Key words: Mineral clay, Infections, Antibacterial agents.

\section{INTRODUCTION}

The intentional consumption of earth materials, such as clays, by humans and animals is known as geophagy, a complex behavior, largely attributed to religious beliefs, cultural practices, psychological disorders, cosmetics, dietary/nutritional needs, and medicinal benefits Wiley, Andrea S. (2006). The oldest evidence of geophagy practiced by humans comes from the prehistoric site Kalambo Fallo on the border between Zambia and Tanzania, where a calciumrich white clay, believed to have been used for healing geophagical purposes Root-Bernstein, R. S. et al. (2000). Throughout history a large number of writers and physicians have commented on geophagy. In the first century $\mathrm{AD}$, physicians mention a famous medicament Known as terra sigillata (earth that has been stamped with a seal) otherwise known as Lemnian Earth. Lemnian Earth was used for many maladies (but most notably for poisoning), and so great was the demand from the $13^{\text {th }}$ to the $14^{\text {th }}$ centuries, that almost every country in Europe strove to find within its boundaries a source of supply, Thompson, C.J.S. et al. (1913).

More recently, the well known German naturopaths, Kneipp, Kuhn, Just, Felke, and others of the last century have contributed to clay's revival in natural treatments. Although geophagy can be found relatively easily in many 
developed countries and among the more tribally oriented people, Abrahams, P.W. and Parasons, J. A.(1996).

The term "clay" refers to a naturally occurring material composed primarily of fine-grained minerals, which is generally plastic at appropriate water contents and will harden with dried or fired. Although clay usually contains phyllosilicates, it may contain other materials that impart plasticity and harden when dried or fired. The associated phases in clay may include materials that do not impart plasticity and organic matter Guggenheim S. (1995).

Mineral Clays come in many colors and hues depending on their sources and mineral content, and their healing properties may vary accordingly. While the trace element and mineral salts in clays partly account for their healing properties, clay is thought to act as a catalyst rather than the actual healing agent Wilson M.J. (2003).

Research in modern uses of high quality healing clays has indicated that it can be effective used to treat skin affections, stomach ulcers, arthritis. These clays can help in the treatment of various conditions such as hemorrhoids, viral infection, mucus colitis, open wounds, anemia, and acne among other ills. Because clays contains both types of dietary iron-ferrous and ferric- in an easily assimilated form, they can help treat anemia. It alleviates allergic discomfort by neutralizing allergen Carretero, M. I. (2002); Plumlee, G.S. and Ziegler, T. L. (2003).

There is a clinical need for new treatment options for serious Grampositive and Gram-negative infections. Recently, introduced agents such as the newer fluoroquinolones and the ketolide telithromycin have limited use as they do not cover methicillin-resistant Staphylococcus aureus (MRSA), or glycopeptide-resistant enterococci (GRE). Clay minerals may prove success in the treatment of these problematic resistance bacterial pathogens Lynda B. W. et al. (2008); Shah PM. (2005) \& Williams, L. B. et al. (2004).

\section{MATERIALS AND METHODS}

This research was fulfilled in the bacteriology laboratory in the College of Dentistry of Al-Anbar University. Four types of mineral clays, \{gray clay (Kaolinite) yellow clay (Fuller's earth), white clay (Bentonite), and pink clay (Common clay) $\}$, were examined to detect their antibacterial activity against two bacterial pathogens that were reported as significant pathogens of skin infections: the first pathogen is Staphylococcus aureus that was isolated from patient (adult male) with skin infection (furunculosis). And the second pathogen is Pseudomonas aeruginosa that was isolated from patient (adult female) with urinary tract infection. Before use in any susceptibility testing, all mineral samples were sterilized by autoclaving at $121^{\circ} \mathrm{C}$ for $15 \mathrm{~min}$. Bacterial strains were grown overnight on suitable medium and diluted with fresh medium to achieve an approximate density of $1 \times 10^{7} \mathrm{cfu} / 400 \mu \mathrm{L}$. Total viable count (TVC) was done to confirm the initial bacterial counts, seriallydiluted bacterial cultures were plated on the Brain heart infusion agar plates and enumerated. After dilution, sterilized mineral clays $(200 \mathrm{mg})$ were introduced into $400 \mu \mathrm{L}$ of media containing the initial pathogen inoculums. The bacteria-mineral mixtures were incubated for $24 \mathrm{~h}$ at $37^{\circ} \mathrm{C}$. Positive controls for growth of bacteria in the absence of clay minerals were included in each series of independent experiments. Negative control growth experiments with clay minerals in Brain heart infusion broth were performed several times throughout the course of the study. The same tests were performed using sterile Brain heart infusion broth as negative control 
without clays. The bacteria - clay mixtures were incubated for $24 \mathrm{~h}$ at $37^{\circ}$ C., Shelley E.H. (2008).

After incubation, the mixtures were subjected to successive 10-fold serial dilutions in the normal saline, mixed with a vortex shaker to ensure dispersion and quantitatively cultured in duplicate onto agar plates to determine the number of viable bacteria Collee J.G. et al. (1998).

\section{RESULTS}

Incubation with the (white clay, gray clay, and yellow clay) revealed incomplete killing of Staphylococcus aureus. That means these clays demonstrated a bactericidal effect against this bacterium. In contrast, incubation with the pink mineral clay resulted in low growth of Staphylococcus aureus. That means these clays demonstrated a bacteriostatic effect against this bacterial isolate (Fig. 1).

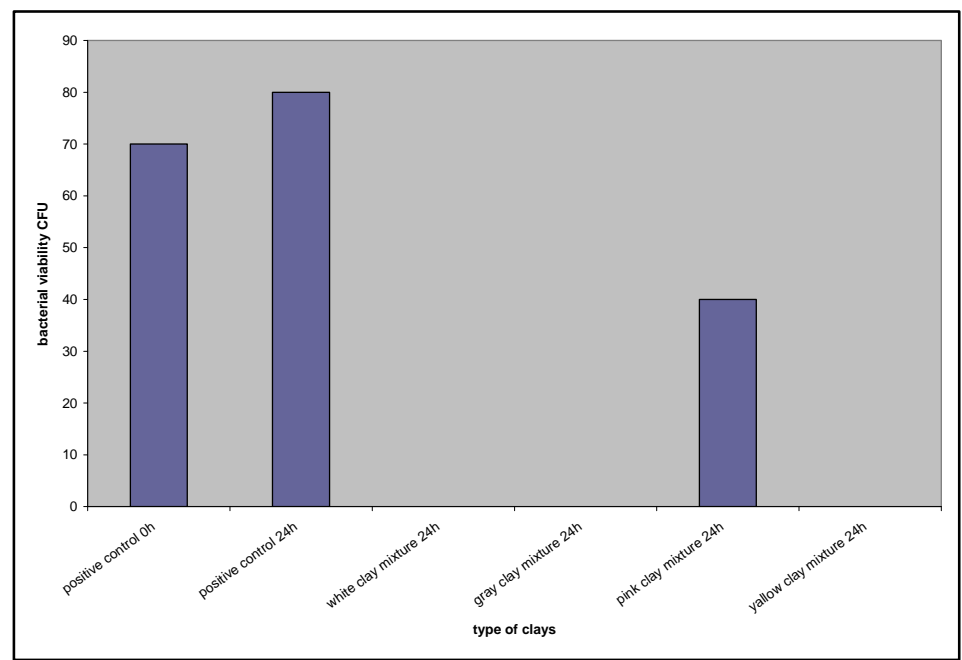

Fig. 1: Antibacterial activity of mineral clays that used in this study against Staphylococcus aureus isolate.

In the presence of the white and gray mineral clay, growth of $P$. aeruginosa isolate was significantly enhanced while growth of this bacterium in presence of the yellow clay was not significantly different compared to bacterial growth in media alone. On the other hand, Pink mineral clay demonstrated a bactericidal effect against P. aeruginosa isolate (Fig. 2).

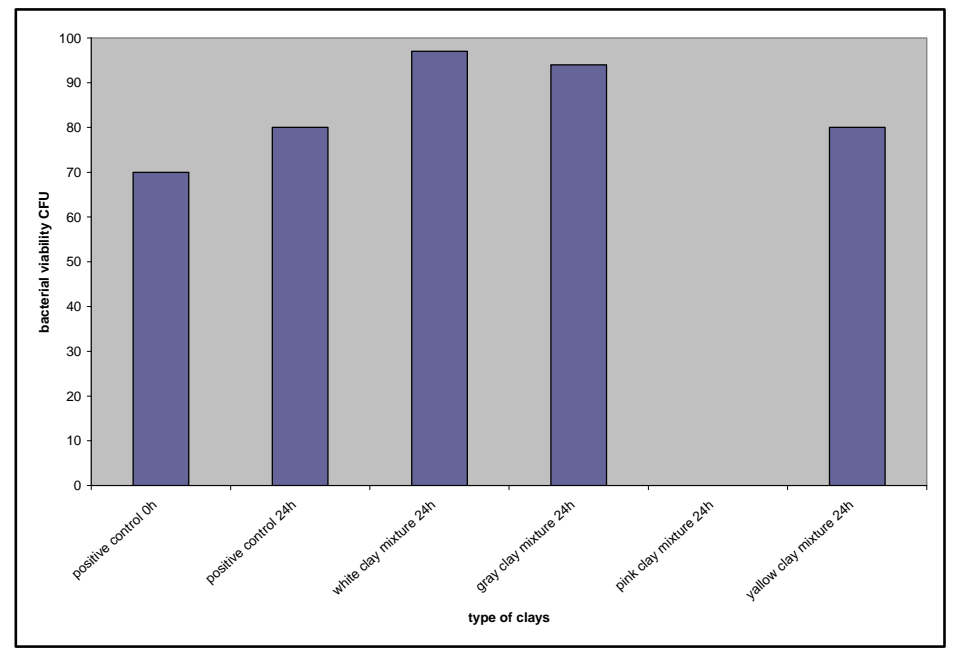

Fig. 2: Antibacterial activity of mineral clays that used in this study against $P$. aeruginosa isolate. 


\section{DISCUSSION}

Worldwide, antibiotic resistant bacterial pathogens have become a serious problem in both the developed and underdeveloped nations. In certain settings, such as hospitals and some child-care locations, the rate of antibiotic resistance is so higher than the usual, low-cost antibiotics are virtually useless for treatment of frequently seen infections. This leads to more frequent use of newer and more expensive compounds, which in turn leads to the rise of resistance to those drugs. A struggle to develop new antibiotics ensues, to prevent losing future battles against infection, Andersson DI. and Levin BR.(1999); Newman D.J. and Cragg GM.(2007), mineral clays could prove an inexpensive bactericidal compounds against resistant bacterial pathogens.

Skin infections, such as Buruli ulcer, is recognized as a global health threat, and recent observations showing that the clay minerals were effective at healing necrotic Buruli ulcer disease prompted our investigations of these geological nanomaterials, Brunet de Courrsou L. (2002). The use of clay minerals in the treatment and healing of skin lesions represents great promise for the development of an inexpensive cure for many skin diseases and topical infections, Williams L. B. et al. (2004).

To assess the effect of the clays minerals on the growth of clinicallyrelevant Gram-negative and Grampositive bacteria, susceptibility testing of Staphylococcus aureus and Pseudomonas aeruginosa was performed in liquid cultures. To achieve poultice consistencies similar to those used to treat skin infection patients, initial bacterial cultures $\left(\sim 10^{7}\right.$ bacteria $\left./ 400 \mu \mathrm{L}\right)$ were mixed with $200 \mathrm{mg}$ of clay minerals and incubated at $37^{\circ} \mathrm{C}$ for 24 hours, Shelley E.H. (2008) In the present study three out of four mineral clays (white clay, gray clay, and yellow clay) were seen to have a good bactericidal effect against Gram-positive bacteria, other hand, pink mineral clay demonstrated a bacteriostatic effect against the same bacteria, and has a bactericidal effect against Gram-negative bacteria . Lynda et al. and Necip) stated that Bentonite may provide a natural pharmacy of antibacterial agents, Lynda B. W. et al. (2009). and Necip G. Bentonites (2009).

Shelley et al. reported that a specific mineral clays have a clear bacteriostatic effect against antibioticresistant $S$. aureus, a single antibioticresistant strain, PRSA, and a multidrug resistant strain, MRSA, and he stated that the same mineral clays have a good bactericidal effect against several antibiotic-sensitive Gram-negative bacteria: E. coli, S. enterica serovar Typhimurium and P. aeruginosa, Shelley E.H., (2008). Zeev et al. reported that the test microorganisms (i.e. Escherichia coli, Staphylococcus aureus, Propionibacterium acnes, Candida albicans) rapidly lost their viability when added to the mineral mud ${ }^{20}$.

Jackson et al (1974) stated that, because of the special quality of specific mineral clays for incorporating various ions, the surface can be either hydrophilic or hydrophobic depending on the charge and available solutes. A hydrophobic surface is inherently organophyllic and could harbors an organic substance that is lethal to bacteria, Rong X. et al. (2008) and Tertre, E. et al. (2006).

Stotzky, G. (1996), reported that clay particles carry a negative electrical charge while toxins in the body carry a positive charge. With the usage of clay, whether internally or externally, the positively charged ions of various toxin are attracted to the negatively charged surface of the clay particle and an exchanged of ions takes place. In this 
process, the toxins are bound and held onto until they can be eliminated (Detoxification).

Enhanced growth of Gramnegative bacteria upon incubation with clay minerals, as demonstrated with white and gray mineral clays, is not an uncommon occurrence, as microorganisms inherently require numerous trace elements to facilitate growth, Jiang, D. (2007).

Gabriel, B. et al. (1972), reported that clay minerals have a positive effect on the survival of Gram-negative Klebsiella aerogenes., clay minerals may serve to protect environmental bacteria from UV irradiation or toxic substances. Additionally, by providing structural support and organic or inorganic nutrient acquisition via its high cationic exchange capacity, clay minerals may protect bacteria and serve as a minimal nutritional sphere for bacterial proliferation, Bitton G, et al. (1972); Lu"nsdorf, H. et al. (2000) and Yanbo, W. et al. (2010).

\section{REFERENCES}

Abrahams, P.W. and Parasons, J.A. (1996). Geophagy in the Tropics: A Literature Review, Geogr. F., 162: 63-72.

Andersson DI. and Levin, BR. (1999). The biological cost of antibiotic resistance. Curr Opin Microbiol. 2: 489-93.

Bitton, G.; Henis, Y. and Lahav, N. (1972). Effect of several clay minerals and humic acid on the survival of Klebsiella aerogenes exposed to ultraviolet irradiation. Appl Microbiol. 23: 870-4.

Brunet de Courrsou L. (2002). Study Group Report on Buruli Ulcer Treatment with Clay. Fifth WHO Advisory Group Meeting on Buruli Ulcer, Geneva, Switzerland, Geneva, Switzerland: WHO.

Carretero, M.I. (2002). Clay minerals and their beneficial effects upon human health. A review. Appl Clay Sci., 21: 155-63.

Collee J.G.; Marmion B.P.; Fraser, A.G. and Simmons, A. (1998). Practical medical microbiology. $15^{\text {th }}$ ed. Churchill Livingstone. New York.

Gabriel, B.; Henis, Y. and Lahav, N. (1972) Effect of Several Clay Minerals and Humic Acid on the Survival of Klebsiella aerogenes Exposed to Ultraviolet Irradiation. American Society for Microbiology. 23(5): 870-874.

Guggenheim S. (1995). Definition of clay and clay mineral: joint report of the AIPEA nomenclature and CMS nomenclature committees. Clays and clays minerals. 43(2)255-256.

Jackson, ML. (1974). Soil Chemical Analysis-Advanced Course.

Madison, WI: University of Wisconsin.

Jiang, D.; Huang, Q.; Cai, P.; Rong, X. and Chen, W. (2007). Adsorption of Pseudomonas putida on clay minerals and iron oxide. Colloids and Surfaces B: Biointerfaces, 54(2): 217-221.

Lu"nsdorf, H.; Erb, RW. and Abraham WR. et al. (2000). 'Clay hutches': a novel interaction between bacteria and clay minerals. Environ Microbiol . 2: 161-8.

Lynda, B. W.; Shelley, E. H.; Rossman, F. G. and Dennis, D. E. (2008). Chemical and Mineralogical Characteristics of French Green Clays Used For Healing. Clays and Clay Minerals; Clay Minerals Society 56 (4): 437-452.

Lynda, B. W.; Shelley, E. H. and Ray, E. F. (2009). Bentonite, Bandaids, and Borborygmi. Mineralogical Society of America. 5 (2): 99-104.

Necip, G. (2009). Bentonites-Clays for Molecular Engineering. Mineralogical Society of America 5(2):89-92.

Newman, DJ. and Cragg, GM. (2007). Natural products as sources of new 
drugs over the last 25 years. J. Nat. Prod. 70: 461-77.

Plumlee, G.S. and Ziegler, T.L. (2003). The medical geochemistry of dusts, soils, and other earth materials. In: Lollar, B.S. (Ed.), Environmental Geochemistry, Treatise on Geochemistry, vol. 9. ElsevierPergamon, Oxford, 7: 263-310.

Rong, X.; Huang, Q.; He, X.; Chen, H.; Cai, P. and Liang, W. (2008). Interaction of Pseudomonas putida with kaolinite and montmorillonite: A combination study by equilibrium adsorption, ITC, SEM and FTIR. Colloid Surface B., 64(1): 49-55.

Root-Bernstein, R. S. and RootBernstein, M. R. (2000). Honey, Mud, Maggots, and Other Medical Marvels, Pan, London.

Shah P. M. (2005). The need for new therapeutic agents: what is the pipeline? Clin Microbiol Infect. 11:36-42.

Shelley, E.H.; Christine, M.R. and Lynda, B.W. (2008). Broad-spectrum in vitro antibacterial activities of clay minerals against antibioticsusceptible and antibiotic-resistant bacterial pathogens. J. Antimicrob Chemother. 61(2): 353-361.

Stotzky G. (1996). Influence of clay minerals on microorganisms. Effect of various clay species, homoionic clays, and other particles on bacteria. Can. J. Microbiol. 12(4):831-48.

Tertre, E.; Caster, S.; Berger, G.; Louber, M. and Giffaut, E. (2006). Surface chemistry of kaolinite and Namontmorillonite in aqueous electrolyte solutions at 25 and $60^{\circ} \mathrm{C}$ : Experimental and modeling study. Geochimica et Cosmochimica Acta, 70(18): 4579-4599.

Thompson, C.J.S. (1913). Terra Sigillata, a Famous Medicament of Ancient Times. In Proceeding of the $17^{\text {th }}$ International congress of medical Sciences ( Section 23, History of medical), London. pp. 433-444.

Wiley, Andrea S. (2006). "Geophagy". in Katz, Solomon H.. Encyclopedia of Food and Culture. New York: Charles Scribner's Sons. 2: 120-121.

Williams, LB.; Holland, M.; Eberl, D.D. and Killer clays! (2004). Natural antibacterial clay minerals. Mineral Soc Bull 139: 3-8.

Wilson M.J. (2003). Clay mineralogical and related characteristics of geophagic materials. J. Chem. Ecol., 29(7):1525-47.

Yanbo W. and Jianzhong H. (2010). Interaction of photosynthetic bacterium, Rhodopseudomonas Palustris, with montmorillonite clay. International Journal of Engineering, Science and Technology. 2 (7): 3643.

Zeev M., Yigal H., Yaacov A., Elina O., Ketil B. S., Aharon O. (2006). Antimicrobial properties of Dead Sea black mineral mud. International Journal of Dermatology. 45(5): 504511. 


\section{ARABIC SUMMARY}

$$
\begin{aligned}
& \text { التأثير المضاد للجراثيم لبعض الترب المعدنية في المختبر }
\end{aligned}
$$

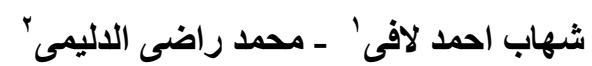

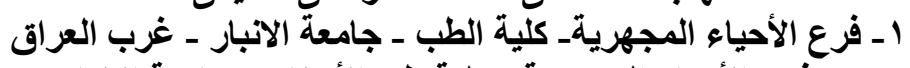

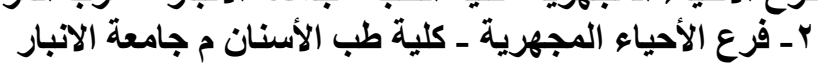

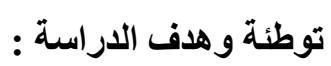

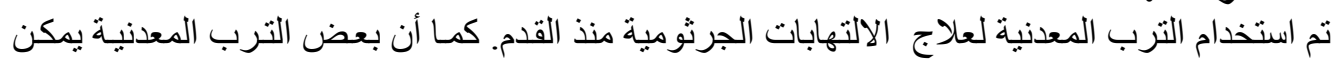

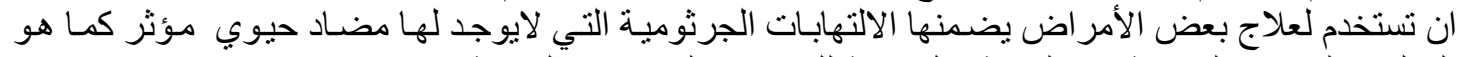

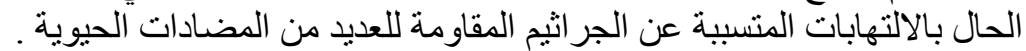

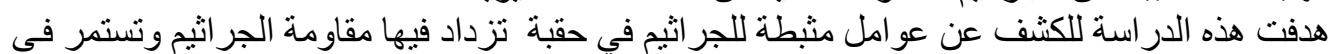

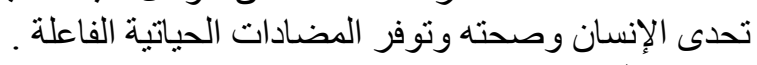

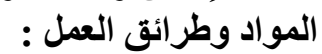

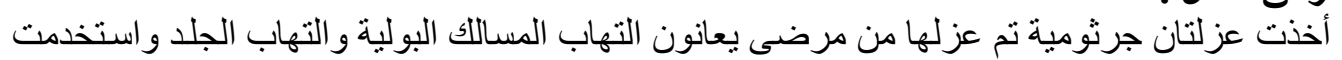

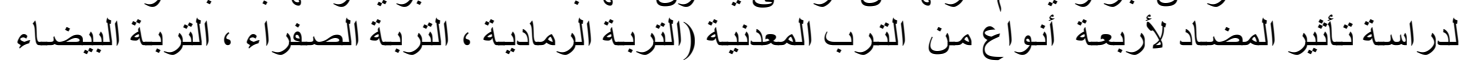
و التربة الزهرية).

تبين أن للأنو اع الثناثة من الترب المعدنية ( التربة البيضاء ، التربة الرمادية والتربـة الصفر اء ) تأثثير النتائج :

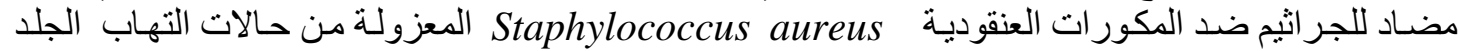
وليس لها تأثثر على الزائفة الزنجارية Pseudomonas aeruginosa المعزولة من التهاب المسالك البولية.

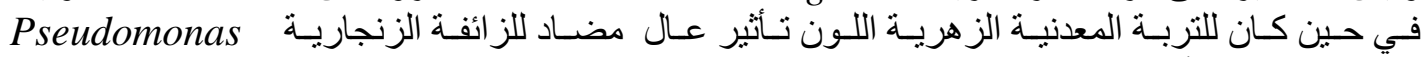

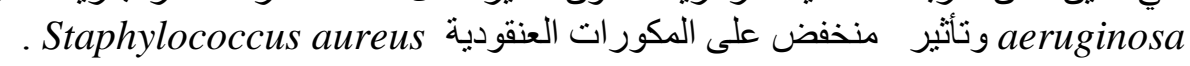

تثير النتائج بان الترب المعدنية مؤثرة على بعض الجر اثيم وقد تكون بمثنابـة علاجـات رخيصـة الثنم

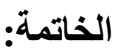
مؤثرة ضد الكثير من الاخماج الجرثومية في الإنسان 